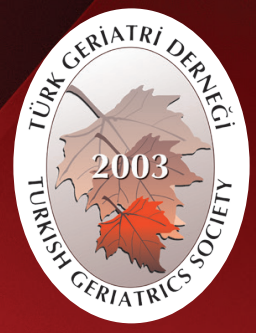

Turkish Journal of Geriatrics

DOI: 10.31086/tigeri.2018240415

2018:21 (2):150-156

- İrem YILDIRIM ${ }^{1}$

- Eda DERLE ÇiFTÇi2

- Münire KILINÇ TOPRAK ${ }^{3}$

\title{
HEADACHE CHARACTERISTICS IN GERIATRIC AGE GROUP ACCORDING TO ICHD-3 BETA VERSION
}

\section{Abstract}

Introduction: The aim of this study was to screen patients aged $\geq 65$ years admitted to the Başkent University Hospital Neurology Polyclinic between 2011 and 2013 and classify them according to the International Classification of Headache Disorders, 3rd edition.

Materials and Method: In total, 175 patients (126 females and 49 males) were screened. First, they were separated into primary and secondary headache groups, and the subgroup headache types were then defined within these groups according to the International Classification of Headache Disorders, 3rd edition; then, the concurrence of accompanying chronic diseases were examined.

Results: In the primary headache group, $21.1 \%$ of the patients had migraine, $39.4 \%$ had tension-type headache, and $51 \%$ had trigeminal neuralgia; in the secondary headache group, $24.2 \%$ of the patients had headache attributed to hypertension, $18.2 \%$ had headache attributed to temporal arteritis, $18.2 \%$ had headache attributed to cervical pathology, and $12.1 \%$ had headache attributed to intracranial mass.

Conclusion: This study was conducted to detect the most commonly seen headache types in geriatric population, and the results of this study are important in terms of increasing awareness of the evaluation of both primary and secondary headaches in geriatric patients. Because the study was conducted with a less patient population, it is important in terms of more accurately demonstrating the factors constituting the etiology of headache in this patient group.

Keywords: Headache; Migraine; Tension-type headache; Trigeminal neuralgia

CORRESPONDANCE

Irem YILDIRIM

Kafkas University, Faculty of Medicine, Neurology Clinic, Kars, Turkey

Phone: 04742252106

e-mail: iremkaftan@gmail.com

Received: 15/01/2018

Accepted: 11/05/2018

Kafkas University, Faculty of Medicine, Neurology Clinic, Kars, Turkey

${ }^{2}$ Başkent University, Faculty of Medicine, Neurology Clinic, Ankara, Turkey Başkent University, Faculty of Medicine, Neurology Clinic, Ankara, Turkey

\section{GERIATRIK YAŞ GRUBU HASTALARDAKi BAŞ AĞRISI ÖZELLIKLERININ ICHD-3 BETA SINIFLANDIRMA ÖLÇEĞINNE GÖRE DEĞERLENDIRILMESI}

\section{Öz}

Giriş: 2011-2013 yılları arasında Başkent Üniversitesi Hastanesi Nöroloji polikliniğine başvuran 65 yaş üstü hasta grubunun taranarak 3. Uluslarası Baş ağrısı Sınıflandırma ölçeğine göre sınıflandırılması amaçlanmıştır.

Gereç ve Yöntem: Araştırmada 126'sı kadın, 49'u erkek toplam 175 hasta tarandı. Önce primer ve sekonder baş ağrısı gruplarına ayrılarak, 3. Uluslararası Baş ağrısı sınıflandırma Ölçeği'ne göre kendi içlerinde alt grup baş ağrısı çeşitleri tanımlandı ve eşlik eden kronik hastalıkların birlikteliği incelendi.

Bulgular: Primer baş ağrısı grubunda hastaların \%21.1'i migren, \%39.4'ü gerilim tipi baş ağrısı, \%51'i trigeminal nevralji olarak tanımlanırken, sekonder baş ağrısı grubunda \%24.2'si hipertansiyon ilişkili, \%18.2'si temporal arterite bağlı, \%18.2 servikal patolojiye bağlı, \%12.1 intrakraniyal kitleye bağıı başağrısı olarak tanımlanmıştır.

Sonuç: Bu çalışma geriatrik popülasyonda en sık görülen başağrısı tiplerinin saptanması için yapılmış olup, çalışmanın sonuçları, yaşlılarda hem primer hem sekonder baş ağıllarını değerlendirmede farkındalığı artırmak açısından önem taşımaktadır. Çalışmanın daha geniş hasta popülasyonu ile yapılması; bu grupta baş ağrısı etyolojisini oluşturan etkenlerin daha doğru bir oranda ortaya konulması açısından önemlidir.

Anahtar sözcükler: Baș ağrısı; Migren; Gerilim baș ağrısı; Geriatri 


\section{INTRODUCTION}

Headache is one of the most frequent neurological complaints both in the general and geriatric populations. The prevalence of headache in the adult population is $46 \%$. Tension-type headache $(43 \%)$ and migraine $(11 \%)$ are types of headaches that most frequently affect adults (1).

The prevalence of headache according to age groups in men and women in the order of increasing ages is as follows: $94 \%-74 \%$ for $21-34$ years, $66 \%-53 \%$ for $55-74$ years, and $55 \%-22 \%$ for $\geq 75$ years (2). Headaches are one of the most common neurological complaints in geriatric patients, and $52 \%$ of patients who are admitted with complaints of headache are in the age group of $\geq 65$ years (3). Although it can be predicted that there would be an increase in the frequency of secondary headaches with increasing age, primary headaches are seen more frequently than secondary headaches in the geriatric population (4).

Hypnic headache and headache attributed to temporal arteritis and Parkinson's disease are the more commonly seen headaches in the geriatric population (5).

When epidemiological headache studies are considered, while many studies have been performed on young and middle-aged populations, the lack of studies on the geriatric population draws attention $(6,7)$. The aim of this study was to classify the variety, frequency, and accompanying clinical characteristics of headaches seen in people aged $\geq 65$ years in Turkey according to the International Classification of Headache Disorders, $3^{\text {rd }}$ edition (beta version) (ICHD-3), and compare these with studies from other countries in the literature.

\section{MATERIALS AND METHOD}

In this retrospective study, medical records of 175 patients aged $\geq 65$ years who were admitted to the
Başkent University Faculty of Medicine Neurology Polyclinic with complaints of headache between 2011 and 2013 were examined. The patients were diagnosed according to their complaints of headache using ICHD-3. Headache was classified using anamnesis information, examination results, and diagnosis criteria of headache types in the ICHD3. Initially, the headache types in the patient group were divided into primary and secondary headaches. Both groups were compared according to age and gender characteristics. Other existing diseases (diabetes mellitus, hypertension, hypothyroidism, coronary artery disease, depression, history of head trauma history, presence of mass or aneurysm in the brain, etc.) in both groups were compared. Subgroups within both groups were formed according to the headache types, and were stated with their percentage ratios.

Statistical analyses were performed with IBM SPSS Statistics for Windows Version 21.0 package software (United States). Numerical variables were presented as mean \pm standard deviation and (minimum-maximum) definitions, whereas categorical variables were presented as number and percentage. Existence of a difference between the two groups in terms of numerical variables was examined using the independent samples t-test. Existence of a difference between the two groups in terms of categorical variables was examined using the chi-square test. Statistical significance was accepted as $p<0.05$.

\section{Financial disclosure}

This study was approved by Baskent University Institutional Review Board (Project no: KA 13/329) and supported by Baskent University Research Fund.

\section{RESULTS}

In total, 175 patients aged $\geq 65$ years were evaluated in this study. The average age of the 
patients was $73.5 \pm 6.9$ years, and 49 were males and 126 were females. The headache types in the patient group were divided into primary and secondary headaches. There were 142 (81.1\%) patients in the primary headache group and 33 (18.9\%) in the secondary headache group. Male/ female ratio in both groups was determined (Table 1). The risk factors of primary and secondary headaches are shown in Table 2. No statistically significant difference was found in the comparison of risk factors between the two headache groups (Table 2).

In the evaluation of the primary headache group, tension-type headache was determined in 56
(39.4\%) patients, trigeminal neuralgia in 44 (51.0\%), migraine without aura in 19 (13.4\%), migraine with aura in $11(7.7 \%)$, primary cough headache in 3 (2.1\%), probable new daily persistent headache in 3 (2.1\%), short-lasting unilateral neuralgiform headache attacks with conjunctival injection and tearing in 2 (1.4\%), and occipital neuralgia in 2 (1.4\%).

Headache attributed to hypertension (24.2\%) was the most common in the secondary headache subgroup, followed by headache attributed to temporal arteritis (18.2\%). Other secondary headache subgroups are shown in Table 3.

Table 1 . Comparison of headache groups according to age and gender characteristics.

\begin{tabular}{lrrr}
\hline & Primary $(\mathbf{n}=142)$ & Secondary $(\mathbf{n}=33)$ & Total $(\mathbf{n}=175)$ \\
\hline Age & $73.4 \pm 7.1$ & $73.9 \pm 6.4$ & $73.5 \pm 6.9$ \\
& $(64-89)$ & $(65-86)$ & $(64-89)$ \\
\hline Gender (M/W) & $39 / 103$ & $10 / 23$ & $49 / 126$ \\
& $(27.5 \% / 72.5 \%)$ & $(30.3 \% / 69.7 \%)$ & $(28 \% / 72 \%)$ \\
\hline
\end{tabular}

Table 2. Risk factors of primary and secondary headache groups.

\begin{tabular}{lccccr}
\hline Risk Factors & \multicolumn{2}{c}{ Primary $(\mathbf{n = 1 4 2 )}$} & \multicolumn{2}{c}{ Secondary $(\mathbf{n}=\mathbf{3 3})$} & $\mathbf{P}$ \\
\hline Diabetes mellitus & 27 & $(19.0 \%)$ & 7 & $(21.2 \%)$ & 0.965 \\
Hypertension & 99 & $(69.7 \%)$ & 22 & $(66.7 \%)$ & 0.894 \\
Hypothyroidism & 15 & $(10.6 \%)$ & 3 & $(9.1 \%)$ & 1.000 \\
Coronary artery disease & 16 & $(11.3 \%)$ & 5 & $(15.2 \%)$ & 0.748 \\
History of head trauma & 8 & $(5.6 \%)$ & 1 & $(3.0 \%)$ & 0.863 \\
Depression & 17 & $(12.0 \%)$ & 2 & $(6.1 \%)$ & 0.501 \\
Aneurism or mass in brain & & - & 4 & $(12.1 \%)$ & 0.001 \\
\hline
\end{tabular}


Table 3. Subgroups of secondary headache $(n=33)$.

\begin{tabular}{llr}
\hline & $\mathbf{n}$ & $\%$ \\
\hline Hypertension related headache & 8 & 24.2 \\
Drug related headache & 1 & 3.0 \\
Headache related to temporal arteritis & 6 & 18.2 \\
Headache secondary to carotid-vertebral disease & 1 & 3.0 \\
Headache related to non-inflammatory disease & 1 & 3.0 \\
Headache secondary to cervical dystonia & 1 & 3.0 \\
Headache related to ischemic stroke disease & 1 & 3.0 \\
Headache secondary to cervical pathology & 6 & 18.2 \\
Headache related to intracranial mass lesion & 4 & 12.1 \\
Glaucoma related headache & 1 & 3.0 \\
Headache secondary to unruptured intracranial saccular aneurism & 1 & 3.0 \\
Headache related to metabolic disorder & 1 & 3.0 \\
Painful trigeminal neuropathy related to intracranial space occupying lesion & 1 & 3.0 \\
\hline
\end{tabular}

\section{DISCUSSION}

Headache is a disorder that should be considered in detail because it does not only disturb the quality of life but can also be a symptom of intracranial and/or systemic diseases. Although there are many studies on young and middle-aged populations regarding the epidemiology of headache, there are very few studies focusing on the geriatric population. When we reviewed the literature, we found that this is the first study categorizing headache in the geriatric population in Turkey according to the ICHD-3.

The principal limitations of this study are that this is a single-center retrospective study conducted with a relatively small patient population. Thus, other primary and secondary headache types that may arise in this age group might not be defined in detail. This has caused the specific diagnoses to be defined less in the headache classification.
In a study in which the frequency of headache was examined according to age groups, the prevalence was determined to be $92 \%$ in women and $74 \%$ in men aged $21-34$ years, $53 \%$ in women and $66 \%$ in men aged $55-74$ years, and 55\% in women and $22 \%$ in men aged $\geq 75$ years (8). According to this, headache prevalence shows a decrease with increasing age. However, because the prevalence of secondary headache was found to be higher in patients aged $\geq 65$ years compared with young patients and both symptomatic and prophylactic treatments have different characteristics in these ages, headaches should be carefully examined in the geriatric population.

In an epidemiologic study by Mei-Ling et al., the prevalence of primary and secondary headaches in patients aged $\geq 65$ years was $81.6 \%$ and $14.9 \%$, respectively (9). In a study by Pascual et 
al. focusing on a similar age group, the proportion of male and female patients was $37 \%$ and $63 \%$, respectively (10). In our study, the prevalence of primary and secondary headaches in the geriatric population was $81.1 \%$ and $18.9 \%$, respectively; the proportion of male and female patients was $28 \%$ and $72 \%$, respectively. According to our results, among the primary headaches in geriatric age group, the prevalence of tension-type headache was $56 \%$, that of migraine without aura was $13.4 \%$, that of migraine with aura was $7.7 \%$, and that of trigeminal neuralgia was $31.0 \%$. Although these ratios are similar to those reported by Lisotto et al. (11), the prevalence of trigeminal neuralgia was $7.7 \%$ in that study, which was lower than that found in our study. In another study, primary stabbing headache was the second most prevalent headache besides migraine and tension-type headache in patients aged $\geq 65$ years (3). In our study, trigeminal neuralgia was also the second most common among primary headaches. The criteria of pain being observed on the first branch of the trigeminal nerve stated in the primary stabbing headache criteria was removed in the ICHD-3 beta version. Because patient histories were not very detailed, primary stabbing headache may not have been separated from the trigeminal neuralgia group, and this may have caused a higher detection rate of trigeminal neuralgia (3). This type of headaches being frequently seen in this age group may be related to cervicogenic headaches, nerve inflammations, and vascular tortuosity being more frequent in geriatric patients $(12,13)$.

In a study examining 193 patients aged $\geq 65$ years, the prevalence of tension-type headaches was $43.0 \%(10)$, and this prevalence is similar to that detected in our study (39.4\%). In another study, the prevalence of tension-type headache was $27 \%$ and that of migraine was $15 \%$ (14). Chronic diseases make the episodes of primary headaches more severe and may accelerate the transformation of headaches from episodic form to chronic daily headaches (6).
In most of the studies evaluating geriatric populations, it was found that the prevalence of tension-type headaches is higher compared with young population. It was suggested that this may be because of the increasing prevalence of cervical osteoarthritis, depression and/or diseases related to depression, and sleep disorders in geriatric patients (14).

In a study conducted in 2004, the ratio of migraine without aura in geriatric patients was $15 \%$, whereas the ratio of migraine with aura was $1.7 \%$ (15). In our study, the ratio of migraine without aura detected as $13.4 \%$ shows a similarity to that study. It is stated that the frequency of migraine transforming into chronic headache in geriatric patients is high (12). It should be kept in mind that pain characteristics may change and this may make diagnosis more difficult in geriatric patients. Compared to the young population, the throbbing characteristic, photophobia and phonophobia relationship, worsening with exercise, and severe headache attack characteristics of headaches diminish over time. On the other hand, autonomic symptoms and bilateral pain are seen more frequently in geriatric patients. The importance of migraine with aura in geriatric patients is still a topic of debate (16). Migraine is closely related to ischemic and hemorrhagic stroke risk, hearth diseases, retinal vasculopathies, and high mortality (17).

In the study by Pascual et al., the ratio of headache attributed to ischemic stroke, temporal arteritis, and intracranial mass in 193 patients aged $\geq 65$ years was found to be significantly higher (15\%) compared with patients aged $<65$ years. (18) In our study, it was found that the total ratio of headaches attributed to these diseases was quite high at $33.3 \%$.

In the study of Pascual et al., the ratio of "benign" cough headache was $1.5 \%$ and occipital neuralgia ratio was $1 \%$. In our study, these ratios were found as $2.1 \%$ and $1.4 \%$, respectively. The importance of cough headache is due to the existence of severe 
secondary factors, especially geriatric patients, such as posterior fossa tumors particularly and non-ruptured intracranial aneurisms, dissection, carotid/vertebrobasilar stenosis, acute sphenoid sinusitis, low cerebrospinal fluid volume, and subdural hematoma. However, most cases are of primary nature and secondary factors are more commonly seen in the younger population (18).

The fact that we did not observe hypnic headache, which is usually seen in patients aged $>60$ years, in the patient group we examined may be due to the low number of participants or due to this headache being rarely seen.

Cluster headache was detected in 2 out of 5 patients in a study screening patients over the age of 65 years (6). In our study, cluster headache was not detected in any patients. Because the first attacks start around the age of 30 years in these types of headaches and become less frequent over time and because the probability of first attacks being observed at later ages is very low, this was seen as an expected outcome (19).

Among secondary headaches, headaches attributed to hypertension were the most frequent (24.2\%), similar to the study by Serratrice et al. (25.9\%) (7).

In the study by Lisotto et al., headache attributed to cervical pathology was reported at a ratio of $26.2 \%$, headache attributed to temporal arteritis was reported at $7.1 \%$, and headache attributed to intracranial mass was reported at 2.4\%. In another study, headache attributed to cervical pathology was determined at a ratio of $18.2 \%$, headache attributed to intracranial mass was determined at $12.1 \%$, and headache attributed to intracranial mass was determined at $12.1 \%(11)$. Temporal arteritis in geriatric patients admitted with headaches is also reported in similar ratios in two other studies $(10,20)$. In our study, headache attributed to temporal arteritis was found at similar ratios with other studies in this age group. This emphasizes the importance of quick differential diagnosis of temporal arteritis, which requires urgent start of treatment, from other headaches. Moreover, the fact that temporal arteritis was the third most prevalent headache cause in the secondary headache group in our study shows its importance in terms of diagnosis and treatment especially in geriatric patients.

Headache attributed to glaucoma was detected only in 1 patient. This was evaluated as the inability of detecting statistically adequate data due to the low number of patients. It was also considered that because elderly patients cannot describe specific eye symptoms, wrong diagnosis or delays in diagnosis may have occurred. When in suspicion, urgent eye consultation and appropriate treatment should be carried out (21).

Headaches are the common side effect of prostaglandin synthetase inhibitors (such as indomethacin), beta blockers (atenolol, metoprolol), sulfonamides (trimethoprimsulfamethoxazole), nitrates (isosorbide dinitrate), ACE inhibitors (captopril), dipyridamole, and alpha 2 stimulants (methyldopa). On the other hand, chronic use and over use of analgesics including NSAIDs can trigger headaches (17). The prevalence in geriatric population is between $1 \%-1.7 \%$ (6). In our study, headache attributed to isosorbide mononitrate was detected in one patient. This can be explained by the number of patients.

The results of the study are important in terms of increasing awareness in evaluation of both primary and secondary headaches in geriatric patients. The study being carried out with a larger patient population is important in terms of demonstrating the factors constituting the headache etiology in this group at a more accurate rate. We believe that prospective and randomized studies investigating geriatric headaches will result in regulations and arrangements in the headache classification scale that can provide benefits in diagnosis and treatment in this special patient group. 


\section{REFERENCES}

1. Wang $Y$, Zhou J, Fan X, et al. Classification and clinical features of headache patients: an outpatient clinic study from China. J Headache Pain 2011;12:562-7. (PMID:21744226).

2. Silberstein SD. Geriatric headache, In: Silberstein SD, Lipton RB, Goadsby PJ. Headache in clinical practice. 2nd edition, Martin Dunitz, Taylor \& Francis Group, London 2002, pp 269-83.

3. Song TJ, Kim YJ, Kim BK, et al. Characteristics of elderly-onset ( $\geq 65$ years) headache. J Clin Neurol Oct 2016;12(4):419-25. (PMID:27819415).

4. Prencipe $M$, Casini $A R$, Ferretti $C$, et al. Prevelance of headache in an elderly population: Attack frequency, disability, and use of medication. J Neurolog Neurosurg Psychiatry 2001;70:377-81. (PMID:11181862).

5. Lipton RB, Bigal ME. Identification or exclusion of secondary headaches. In: Migraine and other headaches. CRC Press, 2006, pp 138-9.

6. Tonini MC, Bussone G. Headache in the elderly: primary forms. Neurological Sciences 2010;31:67-71. (PMID:20464587).

7. Serratrice G, Serbanesco F, Sambuc R. Epidemiology of headache in elderly correlations with life conditions and socio-professional environment. Headache Mar 1985;25(2):85-9. (PMID:3988504).

8. Waters WE. The pontypridd headache survey. Headache Jul 1974;14(2):81-90. (PMID:4854994).

9. Tai ML, Jivanadham JS, Tan CT, et al. Primary headache in the elderly in South-East Asia. J Headache Pain 2012;13:147-57. (PMID:22422347).

10. Pascual J, Berciano J. Experience in the diagnosis of headaches that start in elderly people. J Neurol Neurosurg Psychiat 1994;57:1255-57. (PMID:7931391).

11. Lisotto C, Mainardi F, Maggioni F et al. Headache in the elderly: a clinical study. J Headache Pain 2004;5:36-41.
12. Edmeads J. The cervical spine and headache. Neurology 1988; 38:1874-78. (PMID:3194065).

13. Love S, Coakham HB. Trigeminal neuralgia: pathology and pathogenesis. Brain Dec 2001;124 (Pt 12):2347-60. (PMID:11701590).

14. Solomon GD, Kunkel RS, Frame J. Demographics of headache in elderly patients. Headache 1990;30: 273-6. (PMID:2354949).

15. Wang X, Li WW, Duan JX, et al. Clinical characteristics and diagnosis and treatment status of headaches in the department of gerontology of a university hospital in China. Neurol Res Oct 2014;36(10):921-4. (PMID:24712392).

17. Ruiz MPM, de la Cruz C, Barón J, et al. Cefaleas en la persona mayor: características de una serie de 262 pacientes. Neurologia 2014;29(6):321-6.(6):321-6. (in Spanish).

20. Van Oosterhout W, Cheung C, Haan J. Primary headache syndromes in the elderly: Epidemiology, diagnosis and treatment. J Clin Transl Res 2016;2(2):45-51.

21. Chen PK, Fuh JL, Wang SJ. Cough headache: a study of 83 consecutive patients. Cephalalgia 2009;29:1079-85. (PMID:19438909).

22. Goadsby PJ, Lipton RB. A review of paroxysmal hemicranias, SUNCT syndrome and other short-lasting headaches with autonomic feature, including new cases. Brain Jan 1997;120 (Pt 1):193209. (PMID:9055807).

23. Serratrice G, Serbanesco F, Sambuc R. Epidemiology of headache in elderly correlations with life conditions and socio-professional environment. Headache Mar 1985;25(2):85-9. (PMID:3988504).

24. Dwolatzky T. New-onset headaches in the elderly: An indicator of underlying disease. Aging Health 2012;8(1):79-88. 